\title{
EFFECT OF LINEAR INVESTMENT ON NATURE AND LANDSCAPE - A CASE STUDY
}

\author{
Marta LISIAK $^{1 *}$, Klaudia BOROWIAK ${ }^{1}$, Jolanta KANCLERZ ${ }^{2}$, \\ Anna ADAMSKA ${ }^{2}$, Janusz SZYMAŃCZYK ${ }^{1}$ \\ ${ }^{1}$ Department of Ecology and Environmental Protection of the Poznan University of Life Sciences, \\ Piatkowska 94C, 60-649 Poznań, Poland \\ ${ }^{2}$ Institute of Land Improvement, Environmental Development and Geodesy \\ of the Poznań University of Life Sciences, Piatkowska 94E, 60-649 Poznań, Poland
}

Received 20 December 2017; accepted 12 March 2018

\begin{abstract}
The effect of road location on natural and landscape elements is presented in this paper. Special care was focused on nature conservation areas located along three proposed road variants. Landscape metrics as a supplemental tool for selection of the most environmentally friendly road variant were here examined. The matrix method was used to analyse the potential negative effect of the road on the nature and landscape. Landscape metrics were found to be a very useful supplemental tool to evaluate the potential negative effect of the planned road on the environment. Moreover, based on our study we can also clearly relate this element to the effect on nature conservation elements. One of the most important features is the possibility to calculate certain metrics based on existing land use information without the need for field analyses, as well as obtaining specific values, which may be more objective than visual landscape assessment.
\end{abstract}

Keywords: road, environment, impact, landscape metrics, nature protection, environmental impact assessment.

\section{Introduction}

Construction of a road is a huge scale investment connected with positive and negative effects. Positive effects include social-economic aspects, such as improvement of transport safety, drivers' comfort, shortening the time and costs of travelling and economic activation of surrounding areas. Negative effects are mainly connected with the effect on the environment (Bohatkiewicz, 2008; Forman, 2000; Dmochowski, Dmochowska, \& Biedugnis, 2015; Jaeger, Schwarz-von Raumer, Esswein, Müller, \& Schmidt-Lüttmann, 2007; Lin, 2015; Nematollahi, Fakheran, \& Soffianian, 2017; Rogula-Kozłowska, Rogula-Kopiec, Klejnowski, \& Błaszczyk, 2013).

An effect on the environment can involve many aspects and scales - from specific plant and animal species, through the water and soil environment, to the total ecosystem (Hawbaker \& Radeloff, 2004; Liu et al., 2008; Schweitzer, 2005). Transport infrastructure development is one of the main causes of habitat fragmentation and land use deformation. Roads influence the landscape mainly through changes of existing elements in particular zones near the road area and through the creation of a new pat- tern of landscape (Liu et al., 2008), which is characterized by a decreased number of patches and their higher isolation, together with increased length of their edges. Usually, the common shape of a certain patch is more complex (McGarigal, Romme, Crist, \& Roworth, 2001), although it can also be simpler (Saunders, Mislivets, Chen, \& Cleland, 2002). As a consequence, decreased stability and resistance to landscape changes can be observed (Richling \& Solon, 2011), and in turn losses of valuable habitats, decrease of biodiversity and creation of ecological barriers can be noted (Hawbaker \& Radeloff, 2004; Rico, Kindlmann, \& Sedlácek, 2007; Sanderson et al., 2002). However, the same road can affect creation of new habitats and migration corridors for many valuable species of plant and animals (Karlson \& Mörtberg, 2015).

A special aspect of a road's effect is the impact on nature conservation areas (Albers, Ando, Bu, \& Wing, 2012; Garriga et al., 2012). Hence, it is highly recommended to project several road locations as alternative variants, to indicate the possibility to avoid protected areas or at least limit the negative effect on such areas (Kiczyńska \&

*Corresponding author. E-mail: lismar@up.poznan.pl 
Weigle, 2003). If it is not possible to locate a road far from protected areas, the range and character of influence is analysed, including such aspects as potential disturbance of the balance of distribution and density of key species, reduction of their population, potential reduction of key habitats, potential decrease of area diversity and area fragmentation (Bohatkiewicz, 2008; Lenart, 2002).

One of the basic environmental management tools to avoid negative effects of planned investments is environmental impact assessment (EIA). The most important features of EIA are complexity concerning causes and effects, the necessity to indicate several variants and the balance between local short-term usage of the environment and maintenance and increase of its long-term productivity. The most common methods used for EIA are the index method, matrix method and net method (Bohatkiewicz, 2008; Jay, Jones, Slinn, \& Wood, 2007; Starzewska-Sikorska, 1994). In the case of road investment a popular approach is the "road-effect zone" method (Forman \& Deblinger, 2000; Freudenberger et al., 2013; Liu et al., 2008; Su et al., 2014; Wu, Lin, Chiang, \& Huang, 2014), as well as the use of landscape metrics together with statistical analysis (Cai, Wu, \& Cheng, 2013; Liu et al., 2008; McGarigal \& Marks, 1995; Roo-Zielińska, Solon, \& Degórski, 2007; Saunders et al., 2002; Su et al., 2014; Wu et al., 2014).

The problem of the effect of a road on the landscape is not well studied (Nita \& Myga-Piątek, 2012; Raszeja, 2002; Sas-Bojarska, 2007). The landscape is usually treated as a separate element of the environment and not related to others. Moreover, evaluation of the landscape is usually independently performed by experts and limited to description of the current status (Sas-Bojarska, 2006, 2007). The reason for this state is the common opinion about landscape assessment as totally subjective and difficult to verify, as well as lack of guidance and good practices of valorisation of changes in the landscape during environmental impact assessment procedures (Giedych, 2016; Łowicki, 2015; Sas-Bojarska, 2006).

The Polish road infrastructure has been transformed dramatically since the beginning of the 21st century. Approximately $975 \mathrm{~km}$ of highways were built in 2007-2016, $1274 \mathrm{~km}$ of express roads and 73 city rings. Concerning assumptions of the National Road Building Programme for 2014-2023, another $2750 \mathrm{~km}$ of highways and express roads will be built in the near future. Moreover, this will be accompanied by city rings and other road investments (Program Budowy Dróg..., 2017).

The aim of the present study was to evaluate the potential effect of a road on natural and landscape elements. The investigations were based on the potential northern ring road of Poznań city, Poland. Special care has been focused on nature conservation areas located along three proposed road variants. Moreover, as landscape analysis is usually omitted in road investments, here we also paid special attention to validate potential effects for these aspects and to indicate potential problems. Landscape metrics as a supplementary tool for selection of the most environmentally friendly road variant were here examined.

\section{Material and methods}

The Polish Law of 03.10.2008 on the provision of information on the environment and its protection, public participation in environmental protection and on environmental impact assessments (Journal of Laws of 2008 No. 199 item 1227) was implemented in Polish law as a consequence of the following European Directives: 2011/92/EU of 13 December 2011 on the assessment of the effects of certain public and private projects on the environment and its 2014/52/EU of 16 April 2014 amendment; 2001/42/ EC of 27 June 2001 on the assessment of the effects of certain plans and programmes on the environment and 92/43/EEC of 21 May 1992 on the conservation of natural habitats and of wild fauna and flora. Under those laws three alternative variants for the planned investment are proposed in this paper. Three of them resolve the given problem with construction of a new road, while the last one is based on avoidance of the undertaking and on further exploitation of the existing national road No. 5.

During designation of particular potential road variants the following assumptions have been made: maintenance of highway technical parameters, omitting the water reservoirs, limitation of disturbance of nature conservation areas, maintaining optimal distance between the road and built-up areas. Additionally a prognosis of road traffic has been evaluated for all analysed variants. This was based on the General Road Traffic Measurement from 2015 (GDDKiA, 2016) for existing roads which would be released thanks to the planned road. The prognosis was made for three time horizons: the present year (2017), the potential year of finishing the investment (2025), and 10 years after completion (2035).

For proper analysis of the effect on natural aspects, the following elements were addressed: influence on and conflict with existing nature conservation areas and ecological corridors.

Effect on the landscape was analysed with the aid of four landscape metrics: edge density (ED), patch density (PD), Shannon diversity index (SHDI) and Simpson's evenness index (SIEI). These parameters were calculated for each variant in buffer zones measuring $100 \mathrm{~m}, 200 \mathrm{~m}$, $500 \mathrm{~m}$ and $1000 \mathrm{~m}$ from the road axis. Landscape metrics were calculated with the aid of Fragstats 4.2 software based on Corine Land Cover 2012.

The last phase included the accumulative effect of the potential northern Poznań ring road on natural and landscape aspects. For this purpose a matrix method was applied. The Leopold matrix was applied in the scale from -1 to 4 , where significance of influence is as follows: -1 - positive influence, 0 - lack of impact, 1 - very weak, 2 - weak, 3 - medium, 4 - very high. The analysis was performed for all investigated variants combined together (in columns and rows) and all types of impacts of the investment with analysed environmental elements. The sum of points for each analysed variant revealed the most favourable environmental variant. 


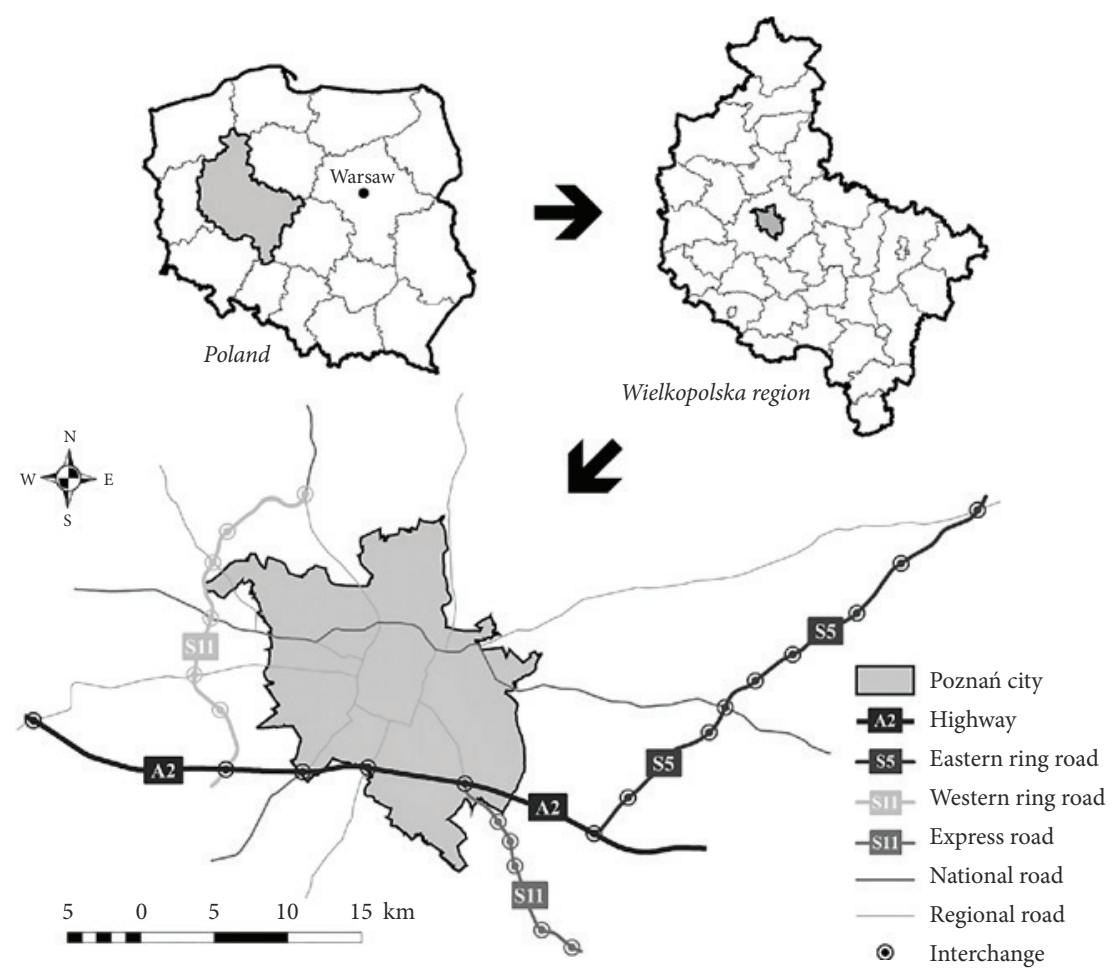

Figure 1. Road system in Poznań city (source: own study based on data from The Central Office of Geodesy and Cartography)

The investigations were conducted for the Poznan city northern ring road. The city is located in the central-western part of Poland. There are ring roads around the city, excluding the northern part (Figure 1).

\section{Results and discussion}

\subsection{Characteristics of proposed investment}

Three alternative ring road variants are here proposed for further environmental analysis - V1, V2 and V3 - as well as the variant "do nothing". In the last case existing roads were investigated with predicted future road traffic. Variants V1 and V2 are conducted in new locations omitting Poznan city from the north side, while variant V3 has been designated based on the old road No. 5 .

Variant V1 would have a length of $47.169 \mathrm{~km}$. Land use in the buffer of $1000 \mathrm{~m}$ is dominated by arable land (61.8\%), as well as forestry and semi-natural areas (31.1\%).

Variant V2 has a length of $50.957 \mathrm{~km}$. Land use is dominated by arable area (64.0\%) and forests and seminatural areas (32.4\%).

Variant V3 predicts the location of the ring road at the existing road and its adaptation to future traffic requirements. This variant location is similar to the variant "do nothing" and the length of the road is $35.628 \mathrm{~km}$. The land use structure is also dominated by artable areas (59.4\%), while forests and semi-natural areas cover $18.9 \%$ of the buffer zone. Urban areas cover 19.5\%, which requires decommissioning of some buildings on the route of variant 3 (Figure 2). All proposed variants are planned according to the requirements of the national law (Journal of Laws of 1999 No. 43, item 430).
Based on the present road structure in the area of planned ring road the proposed road would take some of the traffic from regional roads. The prognosis of the road traffic has been based on the present traffic on existing roads. The mean daily car traffic is at the level of 14524 cars, with the highest number of passenger cars (11 766) (Table 1).

It is predicted that the number of cars will increase in the future. The mean annual traffic for 2017 was assessed at the level of 15914 vehicles, which is an increase of 9.6\% in comparison to 2015. In 2025 the number of vehicles is predicted to be 19663 , which is about $35.4 \%$ more than in 2015. In 2035 the number of cars will reach 25106 (which is about $72.9 \%$ in comparison to 2015) (Table 2).

\subsection{Analysis of environmental impact on nature}

The area through which the proposed highway passes is rich in nature conservation areas. There are nine Natura 2000 network areas of habitats and three of bird areas, three landscape parks, 15 nature reserves and 8 landscape protected areas (Figure 2).

All proposed variants would cross some nature conservation areas, but the greatest effect would be noted for variants V1 and V2. Variant V1 would go through two landscape parks, one Natura 2000 habitat area and one landscape protected area. The length of VI crossing nature conservation areas would be $23.038 \mathrm{~km}$ (48.8\% of the total length). Variant V2 would cross one landscape park, one Natura 2000 bird area, one landscape protected area and two Natura 2000 habitat areas. The length of V2 crossing nature conservation areas would be $15.390 \mathrm{~km}(30.2 \%$ of the total length). Variant V3 and variant 0 would cross only one landscape park for the length of $6.157 \mathrm{~km}(17.3 \%$ of total length) (Table 3). 


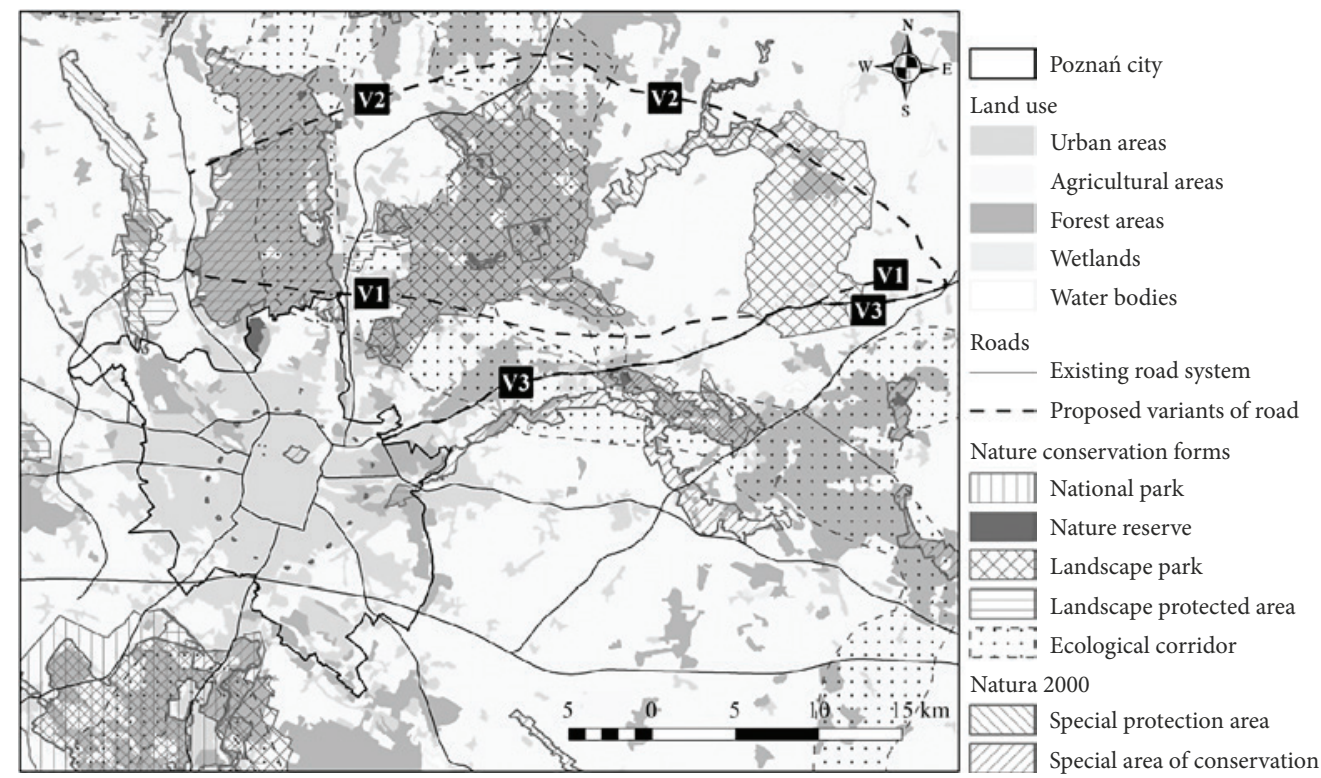

Figure 2. Location of proposed variants in relations to nature conservation areas

(source: own study based on Corine Land Cover 2012 and data from The General Directorate for Environmental Protection)

Table 1. Number of vehicles at analysed roads and proposed northern Poznań ring road (source: own studies based on GDDKiA, 2016)

\begin{tabular}{|l|c|c|c|c|c|}
\hline \multirow{2}{*}{ Vehicle structure } & $\begin{array}{c}\text { Existing regional } \\
\text { road No. 187 }\end{array}$ & $\begin{array}{c}\text { Existing regional } \\
\text { road No. 196 }\end{array}$ & $\begin{array}{c}\text { Existing regional } \\
\text { road No. 197 }\end{array}$ & \multicolumn{2}{|c|}{$\begin{array}{c}\text { Vehicles traffic at proposed Poznań } \\
\text { northern ring road }\end{array}$} \\
\cline { 2 - 6 } & \multicolumn{3}{|c|}{ Number of vehicles } & Number of vehicles & Percentage (\%) \\
\hline Motorcycles & 56 & 134 & 22 & 127 & 0.9 \\
\hline Passenger cars & 4092 & 13585 & 1934 & 11766 & 7.9 \\
\hline Delivery vans & 431 & 1252 & 220 & 1337 & 9.2 \\
\hline Lorries & 529 & 1485 & 215 & 153 & 1.1 \\
\hline Buses & 21 & 217 & 17 & 14524 & 100.0 \\
\hline Total & 5129 & 16673 & 2408 & & \\
\hline
\end{tabular}

Table 2. Number of vehicles at northern Poznań ring in 2017 and prognosis for 2025 and 2035

\begin{tabular}{|l|c|c|c|}
\hline \multirow{2}{*}{$\begin{array}{c}\text { Vehicles } \\
\text { structure }\end{array}$} & \multicolumn{3}{|c|}{ Number of vehicles } \\
\cline { 2 - 4 } & year 2017 & year 2025 & year 2035 \\
\hline Motorcycles & 127 & 127 & 127 \\
\hline Passenger cars & 12983 & 16256 & 21013 \\
\hline Delivery vans & 1186 & 1303 & 1449 \\
\hline Lorries & 1465 & 1824 & 2364 \\
\hline Buses & 153 & 153 & 153 \\
\hline Total & 15914 & 19663 & 25106 \\
\hline
\end{tabular}

There is also the central-northern Ecological Corridor located in this area (Figure 2). All of the analysed variants would cross this area. Variant V1 would cross the ecological corridor for the length of $15.882 \mathrm{~km}$, variant V2 $13.260 \mathrm{~km}$, and variant V3 and " 0 " for the length of $9.625 \mathrm{~km}$.
The area of the potential ring road passes through areas rich in protected sites and ecological corridors. Hence, there is no possibility to locate any variant without impacting on protected areas, and in the case of developing the existing road it almost impossible to perform. The analysed protected areas and ecological corridors also play an important role as migration pathways of several animal species. The proposed investment may make animal migration difficult or even impossible and cause deaths as a consequence of car accidents. It is also indirectly connected with fragmentation of ecosystems and degradation of habitats, as well as deterioration of conditions as a result of emission of pollution and noise (Bohatkiewicz, 2008; Forman \& Alexander, 1998; Forman \& Deblinger, 2000; Garriga et al., 2012; Kiczyńska \& Weigle, 2003; Saunders et al., 2002). One of the simplest ways to allow migration of animals is construction of animal crossings (Jędrzejewski et al., 2006). It is significantly difficult to reduce the indirect effect of the road on fauna and flora. Several investigations indicate many influencing factors (Forman \& Alexander, 1998; Forman \& Deblinger, 2000; Garriga et al., 2012; Saunders et al., 2002). 
Table 3. Collisions of proposed ring road variants with nature conservation forms

\begin{tabular}{|l|c|c|}
\hline \multirow{2}{*}{ Nature conservation forms } & \multicolumn{2}{|c|}{ Range of collision } \\
\cline { 2 - 3 } & $\begin{array}{c}\text { Length of section } \\
{[\mathrm{km}]}\end{array}$ & $\begin{array}{c}\text { Percentage } \\
{[\%]}\end{array}$ \\
\hline \multicolumn{2}{|c|}{ Variant V1 } \\
\hline Landscape park & 13.154 & 27.9 \\
\hline $\begin{array}{l}\text { Natura 2000 - Special area } \\
\text { of conservation }\end{array}$ & 9.884 & 20.9 \\
\hline Landscape protected area & 7.023 & 14.9 \\
\hline Total length of collision & 23.038 & 48.8 \\
\hline \multicolumn{2}{|c|}{ Variant V2 } \\
\hline Landscape park & 7.960 & 15.6 \\
\hline $\begin{array}{l}\text { Natura 2000 - Special } \\
\text { protection area }\end{array}$ & 0.666 & 1.3 \\
\hline $\begin{array}{l}\text { Natura 2000 - Special area } \\
\text { of conservation }\end{array}$ & 7.165 & 14.1 \\
\hline Landscape protected area & 5.763 & 11.3 \\
\hline Total length of collision & 15.390 & 30.2 \\
\hline \multicolumn{2}{|c|}{ Variant V3 and variant “0” } \\
\hline Landscape park & 6.157 & 17.3 \\
\hline Total length of collision & 6.157 & 17.3 \\
\hline
\end{tabular}

A)

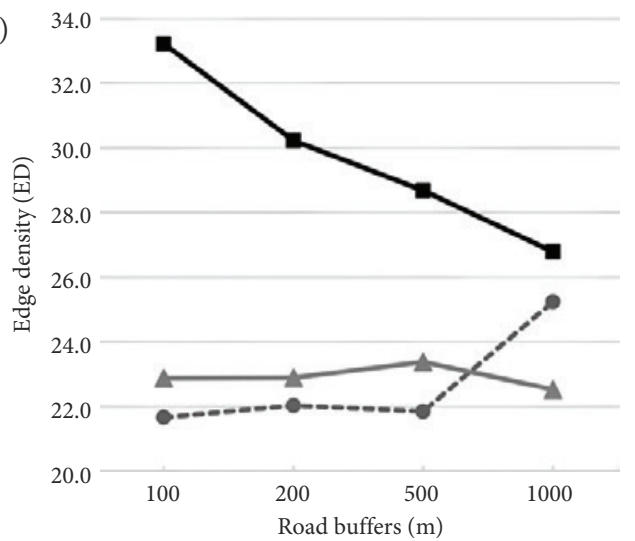

C)

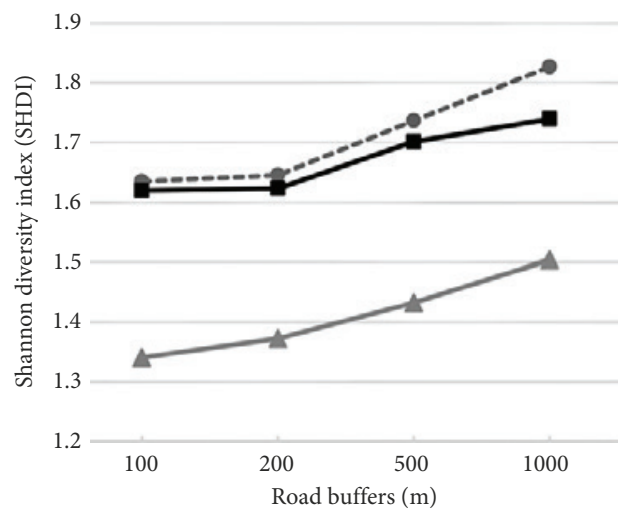

\subsection{Assessment of impact on the landscape}

The planned investment area is varied in regard to landscape structure, which affects the diversity of landscape metrics for analysed variants.

The landscape structure in variant V1 is characterised by patches with concentrated and regular shapes, which is revealed by the lowest value of edge density (ED). Patch density (PD) is also the lowest, but does not vary in comparison to other variants. The landscape is the most varied in comparison to the other variants, which is confirmed by Shannon's diversity index (SHDI). Values of Simpson's evenness index (SIEI) indicate unequal proportions between areas of certain patches.

In the case of variant V2, despite similar patch density (PD) as in the other variants, a higher mean value of edge density (ED) characterizes the less cohesive and regular shape of particular patches. Variant $\mathrm{V}$ is located mainly in arable and forest areas; hence it is less varied, dominated by two types of land use (the lowest levels of SHDI and SIEI).

Variant V3 and variant " 0 " are characterized by high landscape diversity. Especially areas located near to the road are diverse in terms of the shape and number of patches (mainly areas with dispersed and irregular builtup areas). Distribution of patches is unequal and mainly associated with the distance to the road, but the proportions between types of patches are similar.

B)

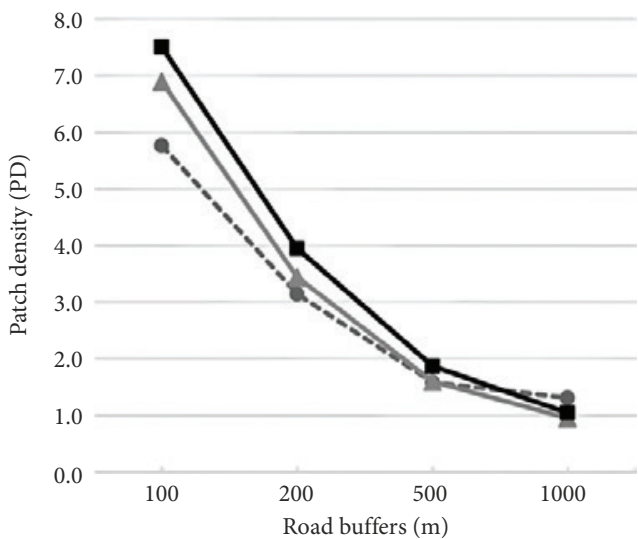

D)

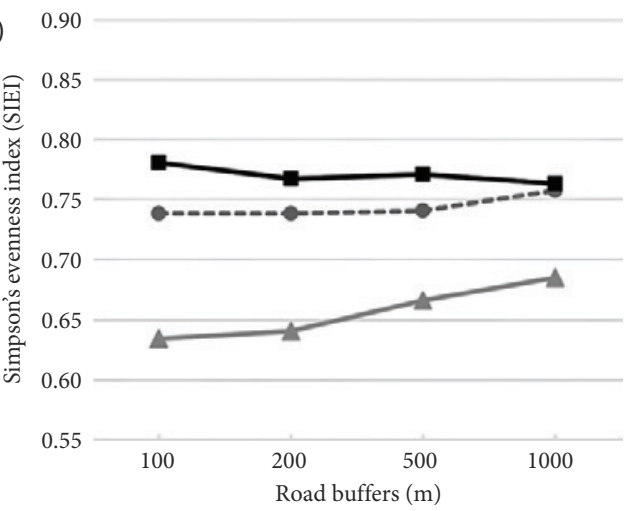

--๑-- Variant V1 - Variant V2 $\rightarrow$ Variant V3

Figure 3. Landscape metrics: edge density (A), patch density (B), Shannon diversity index (C), Simpson's evenness index (D) (source: own study) 
Patch density decreases in relation to the distance from the road in all analysed variants. Together with the distance from the road there are new types of land use, and the landscape becomes more varied. However, the area proportions of various types of patches are similar in a particular variant and are independent from the distance from the road (Figure 3).

Development of road transport can cause many deleterious effects on the environment, including the landscape. The landscape in areas located in the way of the proposed ring road is diverse. The most valuable areas were found on the route of variant V1. There are dispersed areas that are mostly less resistant to secondary deformations caused by the proposed investment (Richling \& Solon, 2011). The highest landscape diversity was noted in areas on the routes of variants V1 and V3. For all variants the patch density increased together with the distance from the road. Similar observations were also previously noted (Liu et al., 2008; Su et al., 2014; Wu et al., 2014). According to Liu et al., (2008) and Su et al. (2014), Shannon's diversity index decreased together with the distance from the road, whereas in our investigations the opposite tendency was observed, which is connected with the appearance of new forms of land use and increase of its diversity.

\subsection{Accumulative environmental assessment of planned investment with the matrix method}

The simplified matrix method was used to analyse the impacts of selected variants of the northern ring road of Poznań city. The analysis was performed for all variants summarized together (in columns and rows) concerning effects of location of the road for analysed environment elements (Table 4).

Table 4. Accumulative matrix of effect (source: own study)

\begin{tabular}{|l|c|c|c|c|}
\hline \multicolumn{1}{|c|}{ Parameters } & $\begin{array}{c}\text { Variant } \\
\text { V1 }\end{array}$ & $\begin{array}{c}\text { Variant } \\
\text { V2 }\end{array}$ & $\begin{array}{c}\text { Variant } \\
\text { V3 }\end{array}$ & $\begin{array}{c}\text { "do nothing" } \\
\text { variant }\end{array}$ \\
\hline $\begin{array}{l}\text { Land occupation } \\
\text { by the planned } \\
\text { road }\end{array}$ & 4 & 4 & 1 & 0 \\
\hline $\begin{array}{l}\text { Change } \\
\text { of land use }\end{array}$ & 2 & 1 & 4 & 0 \\
\hline $\begin{array}{l}\text { Vehicle } \\
\text { transport }\end{array}$ & -1 & -1 & -1 & 4 \\
\hline $\begin{array}{l}\text { Collision } \\
\text { with nature } \\
\text { conservation } \\
\text { areas }\end{array}$ & 3 & 2 & 1 & 1 \\
\hline $\begin{array}{l}\text { Collision } \\
\text { with ecological } \\
\text { corridors }\end{array}$ & 3 & 1 & 2 & 2 \\
\hline $\begin{array}{l}\text { Landscape } \\
\text { structure }\end{array}$ & 3 & 2 & 1 & 1 \\
\hline $\begin{array}{l}\text { Landscape } \\
\text { diversity }\end{array}$ & 4 & 1 & 4 & 2 \\
\hline TOTAL & 18 & 10 & 16 & 10 \\
\hline
\end{tabular}

Accumulative matrix analysis with selected parameters revealed that the largest negative effect (18 points) would be noted for variant V1. The most positive variant from an ecological point of view would be variants V2 and " 0 " (10 points). The most affected elements influencing total value were land occupied by the road and effect on landscape diversity. In the case of variant " 0 " the largest effect was noted for vehicle transport, as this road is not adjusted to the predicted future number of vehicles. This in turn may cause a negative effect on road safety and travel comfort. In our opinion the best solution for the proposed road would be variant $\mathrm{V} 2$.

\section{Conclusions}

Four variants of the road ring were here proposed; three variants were based on a certain location, while the last one was based on a "do nothing" approach. All variants were analysed in regard to the impact on protected areas and the landscape. Considering the predicted traffic it was concluded that the most environmentally friendly would be variant $\mathrm{V} 2$.

Landscape metrics are a very useful supplemental tool to analyse the potential negative effect on the environment. Moreover, based on our study we can also clearly relate this element to the effect on nature conservation elements.

One of the most important features is the possibility to calculate certain metrics based on existing land use information, as well as obtaining particular values, which can be more objective than visual landscape assessment.

\section{Acknowledgements}

Project Corine Land Cover 2012 in Poland was implemented by the Institute of Geodesy and Cartography and supported by the European Union. Results of the project presented here were downloaded from the website of the General Inspectorate of Environmental Protection in Poland clc.gios.gov.pl.

\section{Contribution}

K. B., M. L. and J. S. conceived of the presented idea; M. L. and J. S. developed the theory and performed the computations; J. K. and A. A. verified the analytical methods; M. L. wrote the manuscript with support from K. B.; K. B. and J. K. helped supervise the manuscript; All authors discussed the results and contributed to the final manuscript.

\section{Disclosure statement}

Investigations presented in manuscript were supported by statutory funds of Faculty of Environmental Engineering and Spatial Management of Poznań University of Life Sciences. 


\section{References}

Albers, H. J., Ando, A. W., Bu, M., \& Wing, M. G. (2012). Roadnetwork agglomeration, road density, and protected-area fragmentation. Letters in Spatial and Resource Sciences, 5(3), 137-150. https://doi.org/10.1007/s12076-012-0078-z

Bohatkiewicz, J. (Ed.) (2008). Podręcznik dobrych praktyk wykonywania opracowań środowiskowych dla dróg krajowych. Biuro Ekspertyz i Projektów Budownictwa Komunikacyjnego EKKOM Sp. z o.o. Kraków (in Polish).

Cai, X., Wu, Z., \& Cheng, J. (2013). Using kernel density estimation to assess the spatial pattern of road density and its impact on landscape fragmentation. International Journal of Geographical Information Science, 27(2), 222-230. http://dx.doi.org/10.1080/13658816.2012.663918

Council Directive 92/43/EEC of 21 May 1992 on the conservation of natural habitats and of wild fauna and flora.

Directive 2001/42/EC of the European Parliament and of the Council of 27 June 2001 on the assessment of the effects of certain plans and programmes on the environment.

Directive 2011/92/EU of the European Parliament and of the Council of 13 December 2011 on the assessment of the effects of certain public and private projects on the environment (codification).

Directive 2014/52/EU of the European Parliament and of the Council of 16 April 2014 amending Directive 2011/92/EU on the assessment of the effects of certain public and private projects on the environment Text with EEA relevance.

Dmochowski, D., Dmochowska, A., \& Biedugnis, S. (2015). Emisja stałych cząstek z liniowych źródeł zanieczyszczenia jako główny czynnik wpływający na poziom stężenia pyłu zawieszonego PM10, PM2,5, PM1,0 w powietrzu atmosferycznym aglomeracji warszawskiej. Rocznik Ochrona Środowiska, 17(2), 1403-1412 (in Polish).

Forman, R. T. (2000). Estimate of the area affected ecologically by the road system in the United States. Conservation Biology, 14(1), 31-35.

https://doi.org/10.1046/j.1523-1739.2000.99299.x

Forman, R. T., \& Alexander, L. E. (1998). Roads and their major ecological effects. Annual Review of Ecology and Systematics, 29(1), 207-231.

https://doi.org/10.1146/annurev.ecolsys.29.1.207

Forman, R. T., \& Deblinger, R. D. (2000). The ecological roadeffect zone of a Massachusetts (USA) suburban highway. Conservation Biology, 14(1), 36-46.

https://doi.org/10.1046/j.1523-1739.2000.99088.x

Freudenberger, L., Hobson, P. R., Rupic, S., Pe’er, G., Schluck, M., Sauermann, J., Kreft, S., Selva, N., \& Ibisch, P. L. (2013). Spatial road disturbance index (SPROADI) for conservation planning: a novel landscape index, demonstrated for the State of Brandenburg, Germany. Landscape Ecology, 28(7), 13531369. https://doi.org/10.1007/s10980-013-9887-8

Garriga, N., Santos, X., Montori, A., Richter-Boix, A., Franch, M., \& Llorente, G. A. (2012). Are protected areas truly protected? The impact of road traffic on vertebrate fauna. Biodiversity and Conservation, 21(11), 2761-2774.

https://doi.org/10.1007/s10980-013-9887-8

GDDKiA. (2016). Generalny Pomiar Ruchu w roku 2015. Generalna Dyrekcja Dróg Krajowych i Autostrad. Retrieved from https://www.gddkia.gov.pl/pl/2551/GPR-2015 (in Polish).

Giedych, R. (2016). Ocena wizualnego wpływu przedsięwzięć na krajobraz - nowe wyzwanie dla ocen środowiskowych. Przestrzeń i Forma, 26, 105-114 (in Polish).
Hawbaker, T. J., \& Radeloff, V. C. (2004). Roads and landscape pattern in northern Wisconsin based on a comparison of four road data sources. Conservation Biology, 18(5), 1233-1244. https://doi.org/10.1111/j.1523-1739.2004.00231.x

Jaeger, J., Schwarz-von Raumer, H. G., Esswein, H., Müller, M., \& Schmidt-Lüttmann, M. (2007). Time series of landscape fragmentation caused by transportation infrastructure and urban development: a case study from Baden-Württemberg, Germany. Ecology and Society, 12(1). https://doi.org/10.5751/ES-01983-120122

Jay, S., Jones, C., Slinn, P., \& Wood, C. (2007). Environmental impact assessment: Retrospect and prospect. Environmental Impact Assessment Review, 27(4), 287-300. https://doi.org/10.1016/j.eiar.2006.12.001

Jędrzejewski, W., Nowak, S., Kurek, R., Mysłajek, R., Stachura, K., \& Zawadzka, B. (2006). Zwierzęta a drogi, metody ograniczania negatywnego wplywu dróg na populację dzikich zwierząt. Zakład Badania Ssaków Polskiej Akademii Nauk. Białowieża (in Polish).

Karlson, M., \& Mörtberg, U. (2015). A spatial ecological assessment of fragmentation and disturbance effects of the Swedish road network. Landscape and Urban Planning, 134, 53-65. https://doi.org/10.1016/j.landurbplan.2014.10.009

Kiczyńska, A., \& Weigle, A. (2003). Jak zapewnić spójność sieci Natura 2000, czyli o korytarzach ekologicznych. Instytut Ochrony Przyrody PAN. Kraków (in Polish).

Lenart, W. (2002). Zakres informacji przyrodniczych na potrzeby Ocen Oddziaływania na Środowisko. EKO-KONSULT. Gdańsk (in Polish).

Lin, S. C. (2015). The width of edge effects of road construction on fauna and ecologically critical road density. Journal of Environmental Engineering and Landscape Management, 23(4), 241-250. https://doi.org/10.3846/16486897.2015.1054290

Liu, S. L., Cui, B. S., Dong, S. K., Yang, Z. F., Yang, M., \& Holt, K. (2008). Evaluating the influence of road networks on landscape and regional ecological risk - a case study in Lancang River Valley of Southwest China. Ecological Engineering, 34, 91-99. https://doi.org/10.1016/j.ecoleng.2008.07.006

Łowicki, D. (2015). Walory widokowe dróg w aglomeracji poznańskiej - przykład Parku Krajobrazowego Puszcza Zielonka. Biuletyn Parków Krajobrazowych Wielkopolski, 21(23), 46-58 (in Polish).

McGarigal, K., \& Marks, B. J. (1995). FRAGSTATS: spatial pattern analysis program for quantifying landscape structure, USDA Forest Service. Technical Reports, PNW-351, Portland.

McGarigal, K., Romme, W. H., Crist, M., \& Roworth, E. (2001). Cumulative effects of roads and logging on landscape structure in the San Juan Mountains, Colorado (USA). Landscape Ecology, 16(4), 327-349. https://doi.org/10.1023/A:1011185409347

Nematollahi, S., Fakheran, S., \& Soffianian, A. (2017). Ecological impact assessment of road networks at landscape scale using spatial road disturbance index (SPROADI). Journal of Environmental Engineering and Landscape Management, 25(3), 297-304. https://doi.org/10.3846/16486897.2016.1255218

Nita, J., \& Myga-Piątek, U. (2012). Ocena walorów widokowych drogi S1 [E75] na odcinku Częstochowa-Sosnowiec. Prace Komisji Krajobrazu Kulturowego, 18, 181-193 (in Polish).

Program Budowy Dróg Krajowych na lata 2014-2023 (z perspektywa do 2025 r.) - Attachment to Resolution No. 105/2017 of the Polish Council of Ministers of July 12, 2017.

Raszeja, E. (2002). Procedury i instrumenty kształtowania krajobrazu na obszarach wiejskich Wielkopolski $w$ aspekcie integracji z Unią Europejska. Studioteka "Zarys" Poznań (in Polish). 
Richling, A., \& Solon, J. (2011). Ekologia Krajobrazu. Wydawnictwo Naukowe PWN, Warszawa (in Polish).

Rico, A., Kindlmann, P., \& Sedlácek, F. (2007). Barrier effects of roads on movements of small mammals. Folia Zoologica, 56(1): 1.

Rogula-Kozłowska, W., Rogula-Kopiec, P., Klejnowski, K., \& Błaszczyk, J. (2013). Wpływ emisji komunikacyjnej na stężenie dwóch form węgla i rozkład ich masy względem wielkości cząstek w aerozolu atmosferycznym obszaru miejskiego. Rocznik Ochrona Środowiska, 15(2), 1623-1644 (in Polish).

Roo-Zielińska, E., Solon, J., \& Degórski, M. (2007). Ocena stanu $i$ przekształceń środowiska przyrodniczego na podstawie wskaźników geobotanicznych, krajobrazowych i glebowych (podstawy teoretyczne i przykłady zastosowań). PAN IGiPZ, Warszawa (in Polish).

Rozporządzenie Ministra Transportu i Gospodarki Morskiej z dnia 2 marca 1999 r. w sprawie warunków technicznych, jakim powinny odpowiadać drogi publiczne i ich usytuowanie. Journal of Laws of 1999 No. 43, item 430 (in Polish).

Sanderson, E. W., Jaiteh, M., Levy, M. A., Redford, K. H., Wannebo, A. V., \& Woolmer, G. (2002). The human footprint and the last of the wild. BioScience, 52(10), 891-904. https://doi.org/10.1641/0006-3568(2002)052[0891:THFATL] 2.0.CO;2

Sas-Bojarska, A. (2006). Oceny oddziaływania na środowisko w ochronie krajobrazu. Aura, 9, 5-6 (in Polish).

Sas-Bojarska, A. (2007). Nowe wyzwania dla architektury krajobrazu-oceny środowiskowe, Czasopismo Techniczne. Architektura, 104(5-A), 83-85 (in Polish).
Saunders, S. C., Mislivets, M. R., Chen, J., \& Cleland, D. T. (2002). Effects of roads on landscape structure within nested ecological units of the Northern Great Lakes Region, USA. Biological Conservation, 103(2), 209-225. https://doi.org/10.1016/S0006-3207(01)00130-6

Schweitzer, L. (2005). Road ecology: science and solutions. Environmental Ethics, 27(1), 109-112.

https://doi.org/10.5840/enviroethics200527147

Starzewska-Sikorska, A. (1994). Ocena oddziaływania na środowisko jako narzędzie planowania przestrzennego. Wydawnictwo Ekonomia i Środowisko. Białystok (in Polish).

Su, S., Xiao, R., Li, D., \& Hu, Y. (2014). Impacts of transportation routes on landscape diversity: a comparison of different route types and their combined effects. Environmental Management, 53, 636-647. https://doi.org/10.1007/s00267-013-0214-6

Ustawa z dnia 3 października 2008 r. o udostępnianiu informacji o środowisku i jego ochronie, udziale społeczeństwa w ochronie środowiska oraz o ocenach oddziaływania na środowisko. Journal of Laws of 2008 No. 199, item 1227 (in Polish).

Wu, C. F., Lin, Y. P., Chiang, L. C., \& Huang, T. (2014). Assessing highway's impacts on landscape patterns and ecosystem services: A case study in Puli Township, Taiwan. Landscape and Urban Planning, 128, 60-71.

https://doi.org/10.1016/j.landurbplan.2014.04.020 